\title{
Invitro efficacy of Pseudomonas fluorescens and Bacillus subtilis against Fusarium oxysporum f. sp. lycopersici
}

\author{
K. Murugavel and R. Kannan* \\ Department of plant pathology, Faculty of Agriculture, Annamalai University, \\ Annamalainagar, Tamilnadu, India \\ *Corresponding author
}

\section{A B S T R A C T}

\section{Keywords \\ Tomato (Solanum lycopersicum L.), Pseudomonas fluorescens, Bacillus subtilis Fusarium oxysporum}

\section{Article Info}

Accepted: 14 June 2020 Available Online: 10 July 2020
Tomato (Solanum lycopersicum L.) is one of the most widely grown vegetable crops in the world. 'Lycopene' produced only by tomato is a natural antioxidant that works effectively to slow the growth of the cancerous cells. Tomato plant is susceptible to various diseases caused by different agents such as Bacteria, Viruses, Nematode, Fungi and Abiotic factors. Among the fungal diseases, wilt caused by Fusarium oxysporum f. sp. lycopersici causes economic loss of tomato production worldwide. PGPR playing a vital role and capable to colonize the plants root system and improve the growth and yield. In this present study biocontrol agents viz, Bacillus subtilis and Pseudomonas fluorescens have been tested against the tomato wilt pathogen Fusarium oxysporum f. sp. lycopersici. In the present study the from among the Pseudomonas isolates collected, the isolate $\mathrm{Pf}_{5}$. collected from Puthur showed the maximum inhibition and significantly inhibited the growth of $F$. oxysporum f. sp. lycopersici $(37.12 \mathrm{~mm})$, which was 58.75 per cent reduction on the growth of the pathogen. In the poisson food technique the maximum reduction in the growth of mycelium is noticed in the isolate $\mathrm{Pf}_{5}$ with $45.89 \mathrm{~mm}, 28.45 \mathrm{~mm}, 16.78 \mathrm{~mm}$ and $8.46 \mathrm{~mm}$ 10, 20, 30 and 40 percent respectively. And among the Bacillus isolate collected the isolate $\mathrm{Bs}_{6}$ collected from Arasur showed the maximum inhibition and significantly inhibited the growth of $F$. oxysporum f. sp. lycopersici $(32.63 \mathrm{~mm})$, which was 63.74 per cent reduction on the growth of the pathogen when compared to control. In poison food technique the maximum reduction in the growth of mycelium is noticed in the isolate $\mathrm{Bs}_{6}$ with $40.48 \mathrm{~mm}$, $31.23 \mathrm{~mm}, 15.78 \mathrm{~mm}$ and $3.23 \mathrm{~mm}$ at $10,20,30$ and 40 percent respectively.

\section{Introduction}

Tomato (Solanum lycopersicum L.) is one of the most widely grown vegetable crops in the world (Pastor et al., 2012). Tomato is used for consumption due to its high nutritive values, antioxidant and curative properties (Sahu et al., 2013). Tomatoes are excellent source of various micronutrients and antioxidants. It has high nutritional values which plays a crucial role in our daily home cooking (Prachi singh et al., 2019). Tomato contains high value of vitamin C, Lycopene, and B-Carotene, which supports and promote good health. The nutritional quality of tomato is mainly determined by its Carotenoid, Potassium, 
Vitamin C and vitamin A content. Ripe tomatoes have high levels of Carotenoids, of which carotenes make up between 90 and 95\% (Guil-Guerrero and Rebolloso-Fuentes, 2009). 'Lycopene' produced only by tomato is a natural antioxidant that works effectively to slow the growth of the cancerous cells (Bhovomik et al., 2012).

Around the globe China ranks first in the world with an area of 14.5 lakh hectares and 41.626 million tonnes of production per annum (Anon., 2015). India occupies second position in the world with respect to area, but occupies only fifth place in terms of production. Total area under tomato cultivation in India is 7.97 lakh ha with a production of 207.08 lakh tonnes (Anonymous 2018). In Tamil Nadu the area under tomato cultivation is 25370 ha with the production of 328.2 tonnes per ha (Dhivya et al., 2018). Tomato plant is susceptible to various diseases caused by different agents such as Bacteria, Viruses, Nematode, Fungi and Abiotic factors (Sahu et al., 2013). Tomato production is hampered by soil borne pathogens such as Fusarium wilt and Bacterial wilt etc. Among the fungal diseases, wilt caused by Fusarium oxysporum f. sp. lycopersici causes economic loss of tomato production worldwide.

Management of Fusarium wilt is mainly done by Chemical pesticides such as Pentachloronitrobenzene (PCNB) and soil fumigants as vapam, chloropicrin and methyl bromide. These agrochemicals are associated with several issues including phytotoxicity, pesticide residue, health hazards and environmental disaster (Stevens et al 2003). So the research was augmenting various biomethods to freeze out the various issues.

PGPR playing a vital role and capable to colonize the plants root system and improve the growth and yield. Plant growth promoting
Rhizobacteria with biocontrol traits can be considered as an alternative to the high doses of pesticides applied on crops to deter the pathogens and reduce the disease severity ((Mahendra Prasad et al., 2019). Many of the PGPR strains produce active metabolize that are inhibitory to pathogen and suppress their growth (Beneduzi et al., 2012). Isolates of Pseudomonas spp. and Bacillus spp. recovered from tomato rhizosphere were positive for $\mathrm{HCN}$ production which is able to control Fusarium wilt of tomato caused by Fusarium sp. (Lachisa and Dabassa 2015). These bacteria have been broadly described for wide range antagonistic activities to combat phytopathogens. (Tariq et al., 2010). Bacillus subtilis is also having significant antagonistic activity against $F$. oxysporum in both laboratory and in vivo conditions. The $B$. subtillis strain EU07 reduced the incidence of disease caused by $F$. oxysporum f. sp. lycopersici by $75 \%$ (Rocha, 2017). In this present study biocontrol agents viz, Bacillus subtilis and Pseudomonas fluorescens have been tested against the tomato wilt pathogen Fusarium oxysporum f. sp. lycopersici.

\section{Materials and Methods}

\section{Dual culture (Dennis and Webster, 1971)}

A nine $\mathrm{mm}$ culture disc obtained from the periphery of the seven days old culture of $F$. oxysporum f.sp. lycopersici was inoculated at $75 \mathrm{~mm}$ approximately away from the edge of the Petri dish containing $15 \mathrm{ml}$ of sterilized and solidified PDA medium. The bacterial antagonist Pseudomonas and Bacillus were streak gently made onto the medium using two days old culture just opposite to the pathogenic culture at equidistance. The zone of inhibition and the mycelial growth of $F$. oxysporum f. sp. lycopersici were recorded. The effective antagonists were selected based on the inhibition of the growth of the pathogen. The per cent inhibition of mycelial 
growth was calculated according to Vincent (1927).

$$
\text { Disease Incidence \% (PDI) }=\frac{\text { Number of infected plants }}{\text { Total number of plants }} \times 100
$$

Where C - Radial growth ( $\mathrm{mm}$ ) in Control, $\mathrm{T}$ $=$ Radial growth $(\mathrm{mm})$ in Treatment

Bioassay of Culture filtrates of the antagonist on the mycelial growth of Fusarium oxysporum f. sp. lycopersici:

Effect of culture filtrates on the growth of F. oxysporum. f. sp. lycopersici (Poison food technique)

The culture filtrates of the antagonists were separately incorporated into sterile PDA melted medium at 10,20 and 30 percent concentrations by means of a sterile pipette. The amended media were transferred to sterile petri dishes separately@15 ml and allowed to solidify. The PDA medium without the culture filtrate served as control. Each plate was inoculated at the centre with seven days old pathogen culture. Three replications were maintained for each treatment. The diameter of the mycelial growth $(\mathrm{mm})$ of the pathogen was measured after 7 days of incubation.

\section{Results and Discussion}

In vitro efficacy of Pseudomonas fluorescens against Fusarium oxysporum f. sp. lycopersici $\left(\mathrm{Fol}_{3}\right)$ (Dual culture)

In general all the native Pseudomonas fluorescens tested significantly inhibited the mycelial growth of $F$. oxysporum f. sp. lycopersici (Table 1). However, among the isolates, the isolate $\mathrm{Pf}_{5}$ collected from Puthoor showed the maximum inhibition and significantly inhibited the growth of $F$. oxysporum f. sp. lycopersici (37.12mm), which was 58.75 per cent reduction on the growth of the pathogen when compared to control. This was followed by the isolates $\mathrm{Pf}_{6}$ and $\mathrm{Pf}_{9}$ in the decreasing order of merit, which inhibited the growth of $F$. oxysporum $\mathrm{f}$. sp. lycopersici by 52.36 and 49.37 per cent over control. The least growth inhibition of the pathogen $(19.27 \%)$ was exhibited by the isolate $\mathrm{Pf}_{4}$.

Efficacy of Pseudomonas fluorescens against Fusarium oxysporum f. sp. lycopersici ( $\mathrm{Fol}_{3}$ ) (Poison food technique)

The results depicted in table 2 showed that the different isolates of Pseudomonas fluorescens significantly inhibited the growth of $F$. oxysporum f. sp. Lycopersici. The maximum reduction in the growth of mycelium is noticed in the isolate $\mathrm{Pf}_{5}$ with $45.89 \mathrm{~mm}$, $28.45 \mathrm{~mm}, 16.78 \mathrm{~mm}$ and $8.46 \mathrm{~mm}$ with percent inhibition of $49.01 \%, 68.38 \%, 81.35 \%$ and $90.60 \%$ at $10 \%, 20 \%, 30 \%$ and $40 \%$ respectively. And the minimum reduction in the growth of mycelium is noticed in the isolate $\mathrm{Pf}_{4}$ with $61.26 \mathrm{~mm}, 38.31 \mathrm{~mm}$, and $27.62 \mathrm{~mm}$ and $16.46 \mathrm{~mm}$ with percent inhibition of $31.93 \%, 57.43 \%, 69.31 \%$ and $81.71 \%$ at $10 \%, 20 \%, 30 \%$ and $40 \%$ respectively.

In vitro efficacy of Bacillus subtilis against Fusarium oxysporum f. sp. lycopersici $\left(\mathrm{Fol}_{3}\right)$ (Dual culture)

In general all the native Bacillus spp. tested significantly inhibited the mycelial growth of F. oxysporum f. sp. lycopersici (Table 3). However, among the isolates, the isolate $\mathrm{Bs}_{6}$. collected from Arasur showed the maximum inhibition and significantly inhibited the growth of $F$. oxysporum f. sp. lycopersici $(32.63 \mathrm{~mm})$, which was 63.74 per cent reduction on the growth of the pathogen when compared to control. The least growth inhibition of the pathogen $(24.18 \%)$ was exhibited by the isolate $\mathrm{Bs}_{4}$. 
Efficacy of Bacillus subtilis against Fusarium oxysporum f. sp. lycopersici $\left(\mathrm{Fol}_{3}\right)$ (Poison food technique)

The results depicted in table 4 showed that the different isolates of Bacillus subtilis significantly inhibited the growth of $F$. oxysporum f. sp. Lycopersici. The maximum reduction in the growth of mycelium is noticed in the isolate $\mathrm{Bs}_{6}$ with $40.48 \mathrm{~mm}$, $31.23 \mathrm{~mm}, 15.78 \mathrm{~mm}$ and $3.23 \mathrm{~mm}$ with percent inhibition of $55.02 \%, 65.30 \%, 82.46 \%$ and $96.41 \%$ at $10 \%, 20 \%, 30 \%$ and $40 \%$ respectively. And the minimum reduction in the growth of mycelium is noticed in the isolate $\mathrm{Bs}_{3}$ with $56.35 \mathrm{~mm}, 46.12 \mathrm{~mm}$, and $30.61 \mathrm{~mm}$ and $18.46 \mathrm{~mm}$ with percent inhibition of $37.38 \%, 48.47 \%, 65.98 \%$ and $79.48 \%$ respectively.

In vitro efficacy of Pseudomonas fluorescens against Fusarium oxysporum f. sp. lycopersici

Among the isolates, the isolate $\mathrm{Pf}_{5}$ collected from Puthur showed the maximum inhibition and significantly inhibited the growth of $F$. oxysporum f. sp. lycopersici $(37.12 \mathrm{~mm})$, which was 58.75 per cent reduction on the growth of the pathogen. In the poisson food technique the maximum reduction in the growth of mycelium is noticed in the isolate $\mathrm{Pf}_{5}$ with $45.89 \mathrm{~mm}, 28.45 \mathrm{~mm}, 16.78 \mathrm{~mm}$ and $8.46 \mathrm{~mm}$ with percent inhibition of $49.01 \%$, $68.38 \%, 81.35 \%$ and $90.60 \%$ at $10 \%, 20 \%$, $30 \%$ and $40 \%$ respectively. There are various modes of actions such as antibiosis, competition for iron through production of siderophores, parasitism that may involve production of extracellular enzymes and induction of plant resistance mechanisms (Naureen et al., 2015). Several earlier workers have suggested that the inhibitory action might be due to production of an antimicrobial arsenal, including hydrogen cyanide (HCN), antibiotics, pyoluteorin, phenazines, pyrrolnitrin, siderophores, cyclic lipopeptides, and 2,4-diacetylphloroglucinol (DAPG), phytohormones, solubilisation of phosphate as well as excrete hydrolytic enzymes, such as protease, cellulase, chitinase, $\beta-1,3$ glucanase (Kumar et al., 2007).

Table.1 In vitro efficacy of Pseudomonas fluorescens against Fusarium oxysporum f. sp. lycopersici $\left(\mathrm{Fol}_{3}\right)$ (Dual culture)

\begin{tabular}{|c|c|c|c|c|}
\hline S. No & Isolates & Locality & $\begin{array}{c}\text { Mycelial growth } \\
(\mathbf{m m})\end{array}$ & $\begin{array}{c}\text { Percent inhibition } \\
\text { over control }(\%)\end{array}$ \\
\hline 1. & $\mathrm{Pf}_{1}$ & Hamumantheertham & $52.46^{\mathrm{d}}$ & 41.71 \\
\hline 2. & $\mathrm{Pf}_{2}$ & Irumathur & $64.23^{\mathrm{g}}$ & 28.63 \\
\hline 3. & $\mathrm{Pf}_{3}$ & Uthangarai & $69.36^{\mathrm{i}}$ & 22.93 \\
\hline 4. & $\mathrm{Pf}_{4}$ & Thippampatti & $72.65^{\mathrm{h}}$ & 19.27 \\
\hline 5. & $\mathrm{Pf}_{5}$ & Puthoor & $37.12^{\mathrm{a}}$ & 58.75 \\
\hline 6. & $\mathrm{Pf}_{6}$ & Arasur & $42.87^{\mathrm{b}}$ & 52.36 \\
\hline 7. & $\mathrm{Pf}_{7}$ & Kollanaikanoor & $56.78^{\mathrm{e}}$ & 36.91 \\
\hline 8. & $\mathrm{Pf}_{8}$ & Mittapalli & $47.58^{\mathrm{c}}$ & 47.13 \\
\hline 9. & $\mathrm{Pf}_{9}$ & Kodamandapatti & $45.56^{\mathrm{d}}$ & 49.37 \\
\hline 10. & $\mathrm{Pf}_{10}$ & Mathur & $60.87^{\mathrm{f}}$ & 32.36 \\
\hline 11. & $\mathrm{Control}^{\mathrm{f}}$ & - & 90.00 & - \\
\hline
\end{tabular}


Table.2 Efficacy of Pseudomonas fluorescens against Fusarium oxysporum f. sp. lycopersici ( $\left.\mathrm{Fol}_{3}\right)$ (Poison food technique)

\begin{tabular}{|c|c|c|c|c|c|c|c|c|c|}
\hline \multirow[b]{2}{*}{ S. No } & \multirow[b]{2}{*}{ Isolates } & \multicolumn{8}{|c|}{ Mycelial growth $(\mathrm{mm})$} \\
\hline & & $10 \%$ & $\begin{array}{c}\text { Percent } \\
\text { inhibition over } \\
\text { control }\end{array}$ & $20 \%$ & $\begin{array}{c}\text { Percent } \\
\text { inhibition } \\
\text { over control }\end{array}$ & $30 \%$ & $\begin{array}{c}\text { Percent } \\
\text { inhibition over } \\
\text { control }\end{array}$ & $40 \%$ & $\begin{array}{c}\text { Percent } \\
\text { inhibition over } \\
\text { control }\end{array}$ \\
\hline 1. & $\mathrm{Pf}_{1}$ & $54.84^{\mathrm{e}}$ & 39.06 & $31.43^{\mathrm{e}}$ & 65.07 & $21.43^{\mathrm{e}}$ & 76.18 & $11.79^{\mathrm{e}}$ & 86.90 \\
\hline 2. & $\mathrm{Pf}_{2}$ & $59.76^{h}$ & 33.60 & $35.46^{h}$ & 60.60 & $25.92^{h}$ & 71.20 & $14.89^{h}$ & 83.45 \\
\hline 3. & $\mathrm{Pf}_{3}$ & $60.56^{i}$ & 32.71 & $37.61^{i}$ & 58.21 & $26.46^{i}$ & 70.60 & $15.36^{\mathrm{i}}$ & 82.93 \\
\hline 4. & $\mathrm{Pf}_{4}$ & $61.26^{j}$ & 31.93 & $38.31^{j}$ & 57.43 & $27.62^{j}$ & 69.31 & $16.46^{j}$ & 81.71 \\
\hline 5. & $\mathrm{Pf}_{5}$ & $45.89^{a}$ & 49.01 & $28.45^{\mathrm{a}}$ & 68.38 & $16.78^{a}$ & 81.35 & $8.46^{\mathrm{a}}$ & 90.60 \\
\hline 6. & $\mathrm{Pf}_{6}$ & $47.46^{b}$ & 47.26 & $28.79^{b}$ & 68.01 & $17.89^{b}$ & 80.12 & $9.23^{b}$ & 89.74 \\
\hline 7. & $\mathrm{Pf}_{7}$ & $55.78^{f}$ & 38.02 & $32.78^{f}$ & 63.57 & $22.71^{\mathrm{f}}$ & 74.76 & $12.63^{f}$ & 85.96. \\
\hline 8. & $\mathrm{Pf}_{8}$ & $53.12^{d}$ & 40.97 & $30.65^{d}$ & 65.94 & $21.35^{\mathrm{d}}$ & 76.27 & $10.96^{d}$ & 87.82 \\
\hline 9. & $\mathrm{Pf}_{9}$ & $51.23^{c}$ & 43.07 & $29.78^{c}$ & 66.91 & $19.67^{c}$ & 78.14 & $10.25^{c}$ & 88.61 \\
\hline 10. & $\mathrm{Pf}_{10}$ & $57.56^{\mathrm{g}}$ & 36.04 & $34.12^{\mathrm{g}}$ & 62.08 & $23.41^{\mathrm{g}}$ & 73.98 & $13.64^{\mathrm{g}}$ & 84.84 \\
\hline 11. & Control & 90.00 & - & 90.00 & - & 90.00 & - & 90.00 & - \\
\hline
\end{tabular}

* Mean of three replications; * In a column, means followed by a common letter are not significantly differ at 5\% level by Duncan's multiple range test (DMRT) Table.3 In vitro efficacy of Bacillus subtilis against Fusarium oxysporum f. sp. Lycopersici $\left(\mathrm{Fol}_{3}\right)$ (Dual culture)

\begin{tabular}{|c|c|c|c|c|}
\hline S. No & Isolates & Locality & Mycelial growth $\mathbf{( m m )}$ & Percent inhibition over control \\
\hline 1. & Bs1 & Hamumantheertham & $51.78^{\mathrm{c}}$ & 42.46 \\
\hline 2. & Bs2 & Irumathur & $62.16^{\mathrm{g}}$ & 30.93 \\
\hline 3. & Bs3 & Uthangarai & $72.65^{\mathrm{j}}$ & 19.27 \\
\hline 4. & Bs4 & Thippampatti & $68.23^{\mathrm{i}}$ & 24.18 \\
\hline 5. & Bs5 & Puthoor & $43.48^{\mathrm{b}}$ & 51.68 \\
\hline 6. & Bs6 & Arasur & $32.63^{\mathrm{a}}$ & 63.74 \\
\hline 7. & Bs7 & Kollanaikanoor & $54.36^{\mathrm{d}}$ & 39.60 \\
\hline 8. & Bs8 & Mittapalli & $59.45^{\mathrm{e}}$ & 33.94 \\
\hline 9. & Bs9 & Kodamandapatti & $60.12^{\mathrm{f}}$ & 33.20 \\
\hline 10. & Bs10 & Mathur & $65.76^{\mathrm{h}}$ & 29.93 \\
\hline 11. & Control & & 90.00 & - \\
\hline
\end{tabular}

* Mean of three replications

* In a column, means followed by a common letter are not significantly differ at 5\% level by Duncan's multiple range test (DMRT) 
Table.4 Efficacy of Bacillus subtilis against Fusarium oxysporum f. sp. lycopersici (Fol ${ }_{3}$ ) (Poison food technique)

\begin{tabular}{|c|c|c|c|c|c|c|c|c|c|}
\hline \multirow[b]{2}{*}{ S. No } & \multirow[b]{2}{*}{ Isolates } & \multicolumn{8}{|c|}{ Mycelial growth(mm) } \\
\hline & & $10 \%$ & $\begin{array}{c}\text { Percent } \\
\text { inhibition over } \\
\text { control }\end{array}$ & $20 \%$ & $\begin{array}{c}\text { Percent } \\
\text { inhibition } \\
\text { over control }\end{array}$ & $30 \%$ & $\begin{array}{c}\text { Percent } \\
\text { inhibition over } \\
\text { control }\end{array}$ & $40 \%$ & $\begin{array}{c}\text { Percent } \\
\text { inhibition over } \\
\text { control }\end{array}$ \\
\hline 1. & Bs 1 & $43.12^{c}$ & 52.08 & $34.48^{c}$ & 61.68 & $18.45^{\mathrm{c}}$ & 79.50 & $7.23^{c}$ & 91.96 \\
\hline 2. & Bs2 & $52.64^{\mathrm{g}}$ & 41.51 & $41.78^{\mathrm{g}}$ & 53.57 & $26.87^{\mathrm{g}}$ & 70.14 & $13.47^{\mathrm{g}}$ & 85.03 \\
\hline 3. & Bs3 & $56.35^{\mathrm{j}}$ & 37.38 & $46.12^{j}$ & 48.75 & $30.61^{j}$ & 65.98 & $18.46^{\mathrm{j}}$ & 79.48 \\
\hline 4. & Bs4 & $55.73^{i}$ & 38.07 & $45.36^{i}$ & 49.60 & $28.78^{i}$ & 68.02 & $17.74^{\mathrm{i}}$ & 80.28 \\
\hline 5. & Bs5 & $42.65^{b}$ & 52.61 & $32.76^{b}$ & 63.60 & $17.65^{b}$ & 80.38 & $5.45^{b}$ & 93.94 \\
\hline 6. & Bs6 & $40.48^{\mathrm{a}}$ & 55.02 & $31.23^{\mathrm{a}}$ & 65.30 & $15.78^{\mathrm{a}}$ & 82.46 & $3.2^{3}$ & 96.41 \\
\hline 7. & Bs 7 & $45.35^{\mathrm{d}}$ & 49.61 & $35.62^{\mathrm{d}}$ & 60.42 & $22.34^{\mathrm{d}}$ & 75.17 & $9.46^{d}$ & 89.48 \\
\hline 8. & Bs8 & $46.89^{e}$ & 47.90 & $37.13^{\mathrm{e}}$ & 58.74 & $23.16^{\mathrm{e}}$ & 74.26 & $11.34^{\mathrm{e}}$ & 87.40 \\
\hline 9. & Bs9 & $49.56^{t}$ & 44.93 & $39.34^{\mathrm{f}}$ & 56.28 & $24.64^{\mathrm{f}}$ & 72.62 & $12.16^{\mathrm{f}}$ & 86.48 \\
\hline 10. & Bs10 & $53.76^{\mathrm{h}}$ & 40.26 & $45.34^{\mathrm{h}}$ & 49.62 & $27.47^{\mathrm{h}}$ & 69.47 & $13.34^{\mathrm{h}}$ & 85.17 \\
\hline 11. & control & \multicolumn{2}{|r|}{90.00} & - & - & - & - & - & - \\
\hline
\end{tabular}

* Mean of three replications

* In a column, means followed by a common letter are not significantly differ at 5\% level by Duncan's multiple range test (DMRT) 
In vitro efficacy of Bacillus subtilis against Fusarium oxysporum f. sp. lycopersici

Among the isolates, the isolate $\mathrm{Bs}_{6}$ collected from Arasur showed the maximum inhibition and significantly inhibited the growth of $F$. oxysporum f. sp. lycopersici $(32.63 \mathrm{~mm})$, which was 63.74 per cent reduction on the growth of the pathogen when compared to control. In poison food technique the maximum reduction in the growth of mycelium is noticed in the isolate $\mathrm{Bs}_{6}$ with $40.48 \mathrm{~mm}, 31.23 \mathrm{~mm}, 15.78 \mathrm{~mm}$ and $3.23 \mathrm{~mm}$ with percent inhibition of $55.02 \%, 65.30 \%$, $82.46 \%$ and $96.41 \%$ at $10 \%, 20 \%, 30 \%$ and $40 \%$ respectively.

The mode of antagonism generally observed with Bacillus spp. is antibiosis (Edwards et al., 1994). This is supported by reports that most Bacillus spp. produce many antibiotics such as bacillomycin, fengycin, mycosubtilin and zwittermicin, which are all effective at suppressing growth of target pathogens in vitro (Pal and Gardener, 2006). This evidence allows the assumption that antibiotics are related to the inhibition of the test pathogen observed in this study. Volatiles from $B$. megaterium KU143 (5-methyl-2-phenyl-1Hindole from $B$. megaterium KU143 and 2butyl 1-octanal, dimethyl disulfide, 2isopropyl-5-methyl-1-heptanol) and Trichoderma (2-butyl 1-octanal) inhibited mycelial growth, sporulation, conidial germination, and aflatoxin production by $A$. flavus on media and rice grains (Mannaa et al., 2017). Thus the present findings corroborates with earlier works.

\section{References}

Anon, (2015) Statistical data of horticultural crops I Tamilnadu. www.tngov.in.

Beneduzi A, Ambrosini A, Passaglia LMP (2012) Plant growth promoting rhizobacteria (PGPR): their potential as antagonists and biocontrol agents. Genet Mol Biol 35(4): 1044-1051.

Bhovomik D, Kumar KPS, Paswan S, Srivastava S (2012) Tomato-A Natural Medicine and Its Health Benefits. Journal of Pharmacognosy and Phytochemistry 1(1): 33 .

Dennis L, Webstar J (1971). Antagonistic properties of species-groups of Trichoderma. The production of non volatile antibiotics. Trans. Bri. Mycol. Soc. 57: 25-39.

Dhivya M, Muthamilan M, Kalaivanan R, Devrajan K, Chinnaiah C (2018) Effect of Oilcakes on the Management of Wilt Disease of Tomato Caused by Fusarium oxysporum f.sp. lycopersici. Int J Curr Microbiol Appl Sci 6(12):2138-2140

Francine Yuriko Otsuka Rochaa, Cristiana Maia de Oliveiraa, Paula Renata Alves da Silvaa, Leona Henrique Varial de Melob, Margarida Goréte Ferreira do Carmoc, José Ivo Baldani (2017) Taxonomical and functional characterization of Bacillus strains isolated from tomato plants and their biocontrol activity against races 1,2 and 3 of Fusarium oxysporum $\mathrm{f}$ sp lycopersici. Applied Soil Ecology 120 8-19.

Guil-Guerrero JL, Rebolloso-Fuentes MM (2009) Nutrient composition and antioxidant activity of eight tomato (Lycopersicon esculentum) varieties. Journal of Food Composition and Analysis 22: 123-129.

Kumar, V., Kumar, A., Verma, V.C., Gund, S.K. and Kharwar, R.N. (2007). Induction of defence enzymes in Pseudomonas fluorescence treated chickpea roots against Macrophomina phaseolina. Indian Phytopath. 60(3): 289-295.

Lachisa L, Dabassa A (2015) Synergetic effect of rhizosphere bacteria isolates 
and composted manure on Fusarium wilt disease of tomato plants. Res $\mathrm{J}$ Microbio 11:20-27

Mahendra Prasad, Srinivasan R, Manoj Chaudhary, Mukesh Choudhary, Lokesh Kumar Jat (2019) Plant Growth Promoting Rhizobacteria (PGPR) for Sustainable Agriculture: Perspectives and Challenges. Elsevier Inc https://doi.org/10.1016/B978-0-12815879-1.00007-0

Mannaa, Mohamed \& Oh, Ji \& Kim, Ki Deok. (2017). Microbe- mediated control of Aspergillus flavus in stored rice grains with a focus on aflatoxin inhibition and biodegradation. Annals of Applied Biology. 171; 376-392.

Pal KK, Gardener BM (2006) Biological control of plant pathogens. The Plant Health Instructor.

Pastor N, Carlier E, Andres J, Rosas SB, Rovera M (2012) Characterization of rhizosphere bacteria for control of phytopathogenic fungi of tomato. J Environ Manage 95: 332-337.

Prachi Singh, Singh HB, Jyoti Singh, Rahul Singh Rajput, Anukool Vaishnav,
Shatrupa Ray, Singh RK (2019) Exploration of multitrait antagonistic microbes against Fusarium oxysporum f.sp. lycopersici. J Appl and Natural Sci 1(2):503 - 510

Sahu DK, Khare CP, Singh HK, Thaku, MP (2013) Evaluation of newer fungicide for management of early blight of tomato in Chhattisgarh. The Bioscan 8(4): 1255-1259.

Stevens C, Khan VA, Rodriguez-Kabana R, Ploper LD, Backman PA, Collins DJ, Brown JE, Wilson MA, Igwegbe ECK (2003) Integration of soil solarization with chemical, biological and cultural control for the management of soil borne diseases of vegetables. Plant and Soil 253: 493-506

Tariq M, Shahnaz dawar, Samreen wahab, Javed zaki (2010) Application of Bacillus species in the control of root rot diseases in crop plants. Arch Phytopathol Plant Prot 43(4):412-418

Vincent JM (1927). Distortion of fungal hyphae in the presence of certain inhibitors. Nature. 59: 850.

\section{How to cite this article:}

Murugavel, K. and Kannan, R. 2020. In vitro efficacy of Pseudomonas fluorescens and Bacillus subtilis against Fusarium oxysporum f. sp. lycopersici. Int.J.Curr.Microbiol.App.Sci. 9(07): 1569-1576. doi: https://doi.org/10.20546/ijcmas.2020.907.182 